\title{
Building 9401-2 Plating Shop Surveillance and Maintenance Plan
}

\author{
May 1999
}

Prepared by the

Y-12 Facility Transition Program

for Depleted Uranium Operations

Oak Ridge, Tennessee 37831-8169

managed by

LOCKHEED MARTIN ENERGY SYSTEMS, INC.

for the

U.S. DEPARTMENT OF ENERGY

under Contract No. DE-AC05-84OR21400 


\section{DISCLAIMER}

This report was prepared as an account of work sponsored by an agency of the United States Government. Neither the United States Government nor any agency thereof, nor any of their employees, makes any warranty, express or implied, or assumes any legal responsibility for the accuracy, completeness, or usefulness of any information, apparatus, product, or process disclosed, or represents that its use would not infringe privately owned rights. Reference herein to trademark, manufacturer, or otherwise, does not necessarily constitute or imply its endorsement, recommendation, or favoring by the United States Government or any agency thereof. The views and opinions expressed herein do not necessarily state or reflect those of the United States Government or any agency thereof. 


\section{DISCLAIMER}

Portions of this document may be illegible in electronic image products. Images are produced from the best available original document. 
APPROVALS

BUILDING 9401-2 PLATING SHOP SURVEILLANCE AND MAINTENANCE PLAN

The following individuals have read and approve of the contents within the following document, Document No. Y/SMS-61.

P.D. Psihogios

9401-2 Building Manager - Depleted Uranium Operations

Moelk/futa

N. K. Newton

Operations Manager - Depleted Uranium Operations

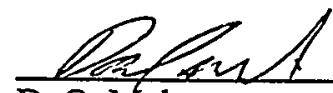

D. O. Melroy

Y-12 Fire Protection Engineering

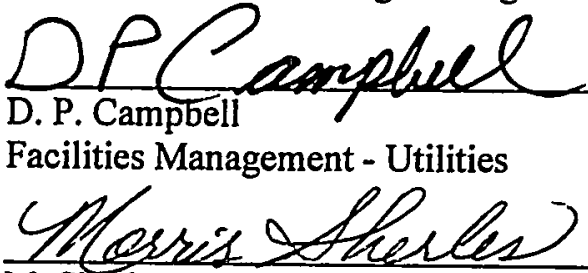

M. Sherles

Facilities Management - Maintenance - 9204-2 crew

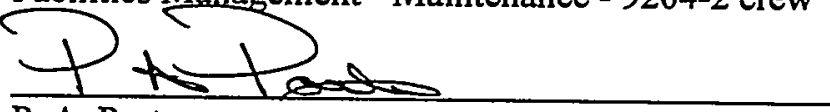

P. A. Porter

Industrial Safety

Wayne O. Lawless

W. O. Lawless

Industrial Hygiene

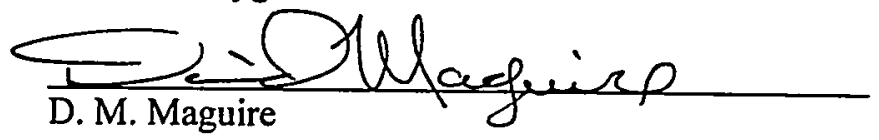

Environmental Management - Water Program

Malls. Bunco

M. S. Burris

Environmental Management - Solid Waste (RCRA)

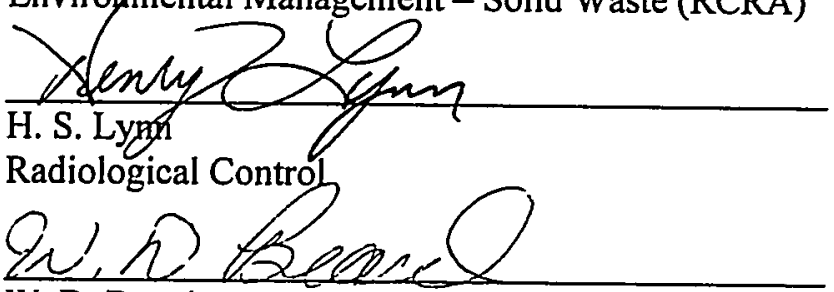

W. D. Beard

Physical Security Group

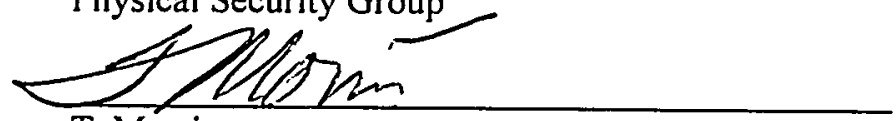

T. Morris

Plant Shift Superintendent's Office $\frac{5-10-99}{\text { Date }}$

$\frac{5-10-99}{\text { Date }}$

$\frac{5-7-99}{\text { Date }}$

$\frac{5 / 13 / 99}{\text { Date }}$

$\frac{5-10-99}{\text { Date }}$

$\frac{5-13-1999}{\text { Date }}$

$\frac{5-6-99}{\text { Date }}$

$\frac{5-12-99}{\text { Date }}$

$\frac{5-12-99}{\text { Date }}$

$\frac{5-12-99}{\text { Date }}$

$\frac{5-12-99}{\text { Date }}$

$5-13-99$

Date 


\section{TABLE OF CONTENTS}

Page

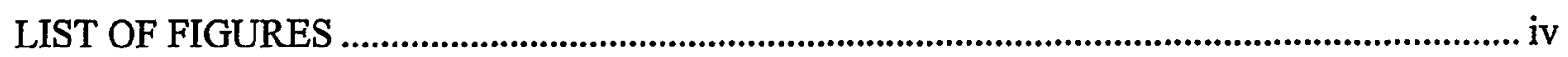

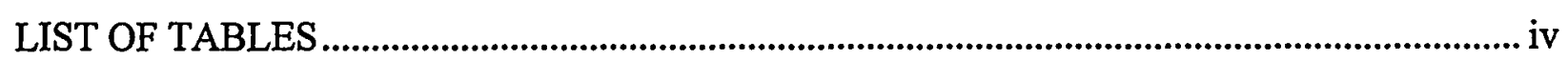

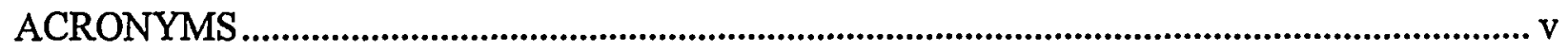

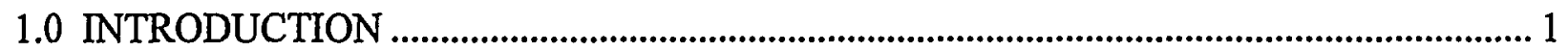

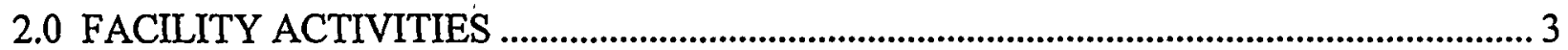

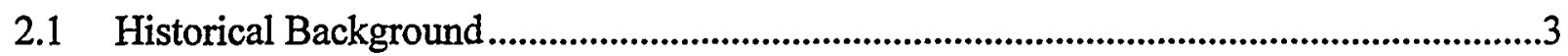

2.2 Facility Description ...............................................................................................................

2.3 Surveillance Activities........................................................................................................6

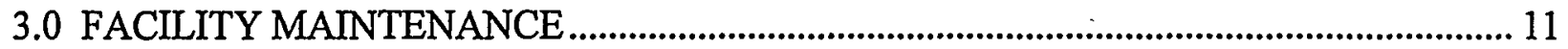

3.1 Planning And Coordination Of Maintenance ............................................................11

3.2 Modification Work ...............................................................................................11

3.3 Seasonal Facility Requirements...........................................................................................12

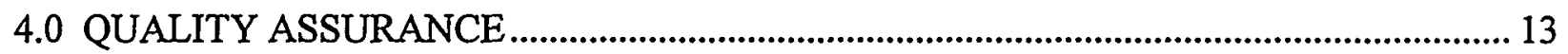

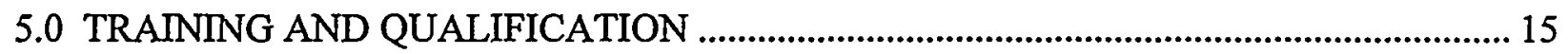

6.0 ENVIRONMENTAL COMPLIANCE/PROTECTION.................................................... 17

6.1 Plating Shop, Building 9401-2 Air Permit ..................................................................18

6.2 Regulatory Files/Documentation............................................................................18

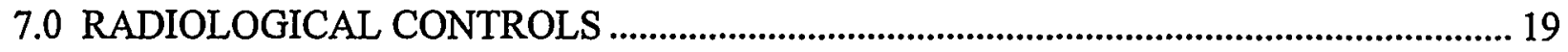

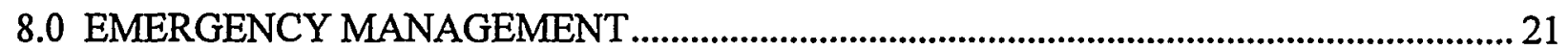

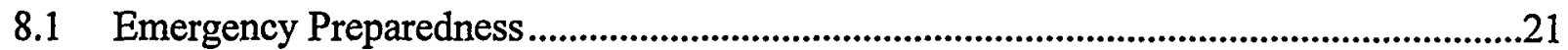

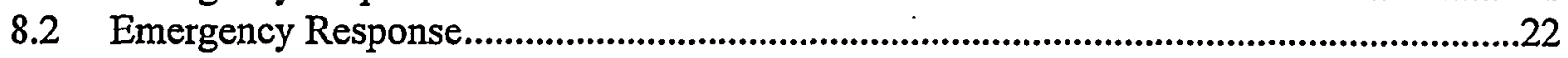

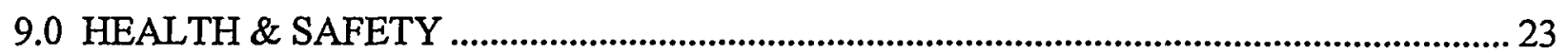

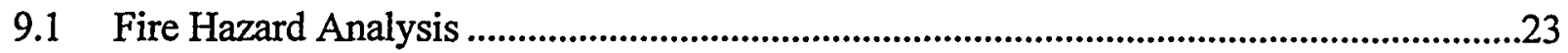

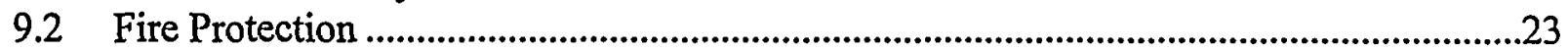

9.3 Occupational Safety And Health ...................................................................................23

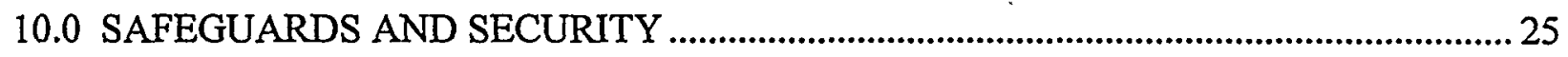

11.0 SURVEILLANCE AND MAINTENANCE ACTIVITIES ............................................ 27

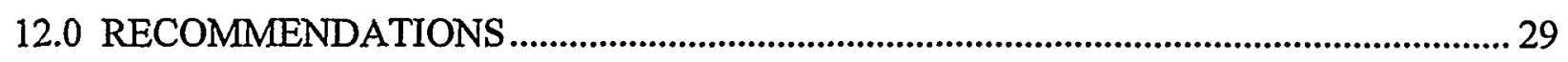

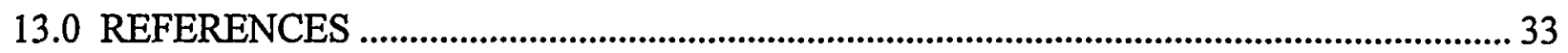

APPENDIX A. DEACTIVATION ACTION ITEM SUMMARY FOR BUILDING 9401-2

APPENDIX B. EXHAUST DUCTWORK AND POTENTIAL RESIDUALS 


\section{LIST OF FIGURES}

Figure 1. Building 9401-2, Equipment Layout and Exhaust ......................................................

Figure 2. Building 9401-2, Inspection Route and Life Safety Equipment .................................9

\section{LIST OF TABLES}

Table 1. Remaining Items, Equipment, and Materials, Building 9401-2 …...............................7

Table 2. Surveillance and Maintenance Activities Schedule, Building 9401-2 …........................27 


\section{ACRONYMS}

CFR

Code of Federal Regulations

$D \& D$

Decontamination and Decommissioning

DOE

Department of Energy

DOT

Department of Transportation

DUO

Depleted Uranium Operations

ENS

Emergency Notification System

EP

Environmental Protection

ET\&I

Equipment, Testing and Inspection

FHA

Fire Hazard Analysis

FMO

Facilities Management Organization

FSET

Facility Safety Evaluation Team

GET

General Employee Training

LCAM

Life Cycle Asset Management

LMES

Lockheed Martin Energy Systems

MAU

Makeup Air Unit

NRMMA

Non-Radioactive Material Management Area

OSHA

Occupational Safety and Health Administration

PA

Public Address System

PM

Preventive Maintenance

PSS

Plant Shift Superintendent

QA

Quality Assurance

RadCon

Radiological Control

RCRA

Resource Conservation and Recovery Act

RMA

Radioactive Material Area

S\&M

Surveillance and Maintenance

WMO

Waste Management Organization 


\subsection{INTRODUCTION}

This document provides a plan for implementing surveillance and maintenance (S\&M) activities to ensure that Building 9401-2 Plating Shop is maintained in a cost effective and environmentally secure configuration until subsequent closure during the final disposition phase of decommissioning. U.S. Department of Energy (DOE) G430.1A-2, Surveillance and Maintenance During Facility Disposition (1997), was used as guidance in the development of this plan.

The S\&M Plan incorporates DOE O 430.1A, Life Cycle Asset Management (LCAM) (1998a) direction to provide for "conducting surveillance and maintenance activities required to maintain the facility and remaining hazardous and radioactive materials, wastes, and contamination in a stable and known condition pending facility disposition." Recommendations in the S\&M plan have been made that may not be requirement-based but would reduce the cost and frequency of surveillance and maintenance activities.

During the course of S\&M activities, the facility's condition may change so as to present an immediate or developing hazard or unsatisfactory condition. Corrective action should be coordinated with the appropriate support organizations using the requirements and guidance stated in procedure Y10-202, Rev. 1, Integrated Safety Management Program, (Lockheed Martin Energy Systems, Inc. (LMES), 1998a) implemented at the Oak Ridge Y-12 Plant and the methodology of the Nuclear Operations Conduct of Operations Manual (LMES, 1999) for the Depleted Uranium Operations (DUO) organization.

The key S\&M objectives applicable to the Plating Shop are to:

- Ensure adequate containment of remaining residual material in exhaust stacks and outside process piping, stored chemicals awaiting offsite shipment, and items located in the Radioactive Material Area (RMA).

- Provide access control into the facility and physical safety to S\&M personnel.

- Maintain the facility in a manner that will protect the public, the environment, and the S\&M personnel.

- Provide an S\&M plan which identifies and complies with applicable environmental, safety, and health safeguards and security requirements.

- Provide a cost effective S\&M program for the plating shop, Building 9401-2. 


\subsection{FACILITY ACTIVITIES}

\subsection{Historical Background}

The general plating facility, Building $9401-2$, is located east of the steam plant on $2^{\text {nd }}$ Street within the exclusion area of the Oak Ridge Y-12 Plant. It was built in the early 1940s as part of the original Y-12 Plant construction. It housed the steam plant operations until the mid 1950s when a replacement facility was constructed. In 1955, Building 9401-2 was converted into a plating shop for the Metal Preparation Division. Over the years the facility has had several modifications and upgrading. The Phase I Hazard Screening Analysis for the Plating Shop (LMES, 1991) and the corresponding approval classify Building 9401-2 as standard industrial, below category 3 facility; therefore, Industrial/Nonnuclear hazard classification was assigned to the building.

In early 1998, the Department of Energy, Oak Ridge Operations, directed the Lockheed Martin Energy Systems, Inc. (LMES), Facility Transition Program, in cooperation with Depleted Uranium Operations (DUO) organization to initiate transition of the building from an operational mode to a surveillance and maintenance status. The deactivation actions were to serve as a bridge between operations and decommissioning aimed at placing the facility in a safe and environmentally compliant condition. Activities included:

- draining and cleaning plating tanks;

- removal of process materials, chemicals, and gas cylinders;

- removal of debris, flammables, oxidizers, and generated wastes;

- de-energizing and disconnecting process equipment, plating tank exhaust fans (Figure 1); and

- disconnecting utilities no longer required.

The listing of deactivation action items completed for Building 9401-2 as of September 30, 1998, is listed in Appendix A. Since then all remaining Resource, Conservation, and Recovery Act (RCRA) accumulation areas have been closed and staged chemicals are awaiting offsite shipment. Completion of these activities has established a safe and environmentally compliant configuration suitable for a long-term S\&M program. The facility is currently being managed by the DUO organization that is responsible for implementation of surveillance and maintenance activities.

\subsection{Facility Description}

Building $9401-2$ is a steel frame, clear span, $42-\mathrm{ft}$ high structure with a built-up roof system. The building has a concrete floor on grade. The concrete floor under the plating operations area is diked. All supply and exhaust ducts and stacks are supported outside the building, and roof 


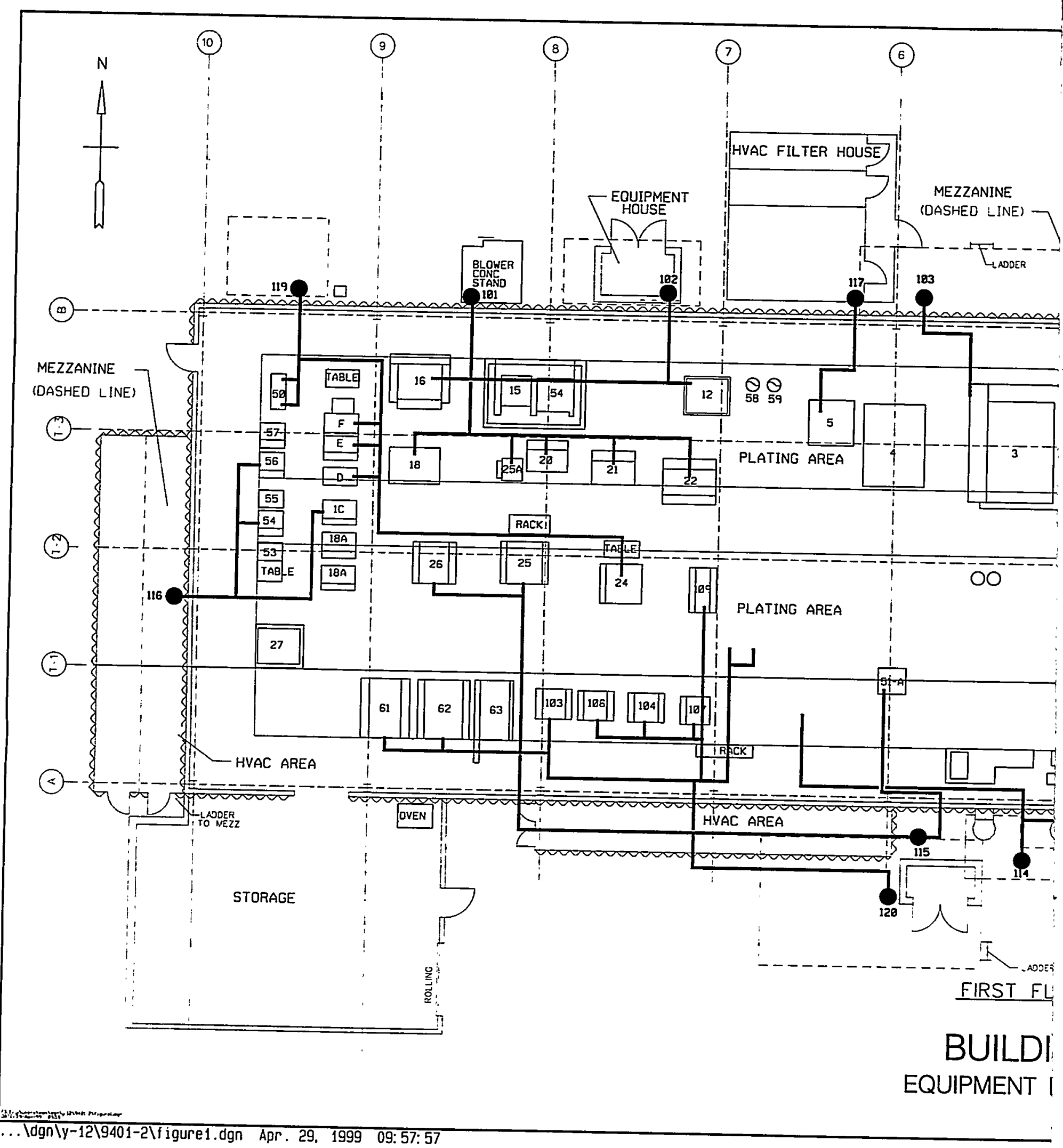

Figure 1. Building 9401-2, Equipment Layout and Exhaust 


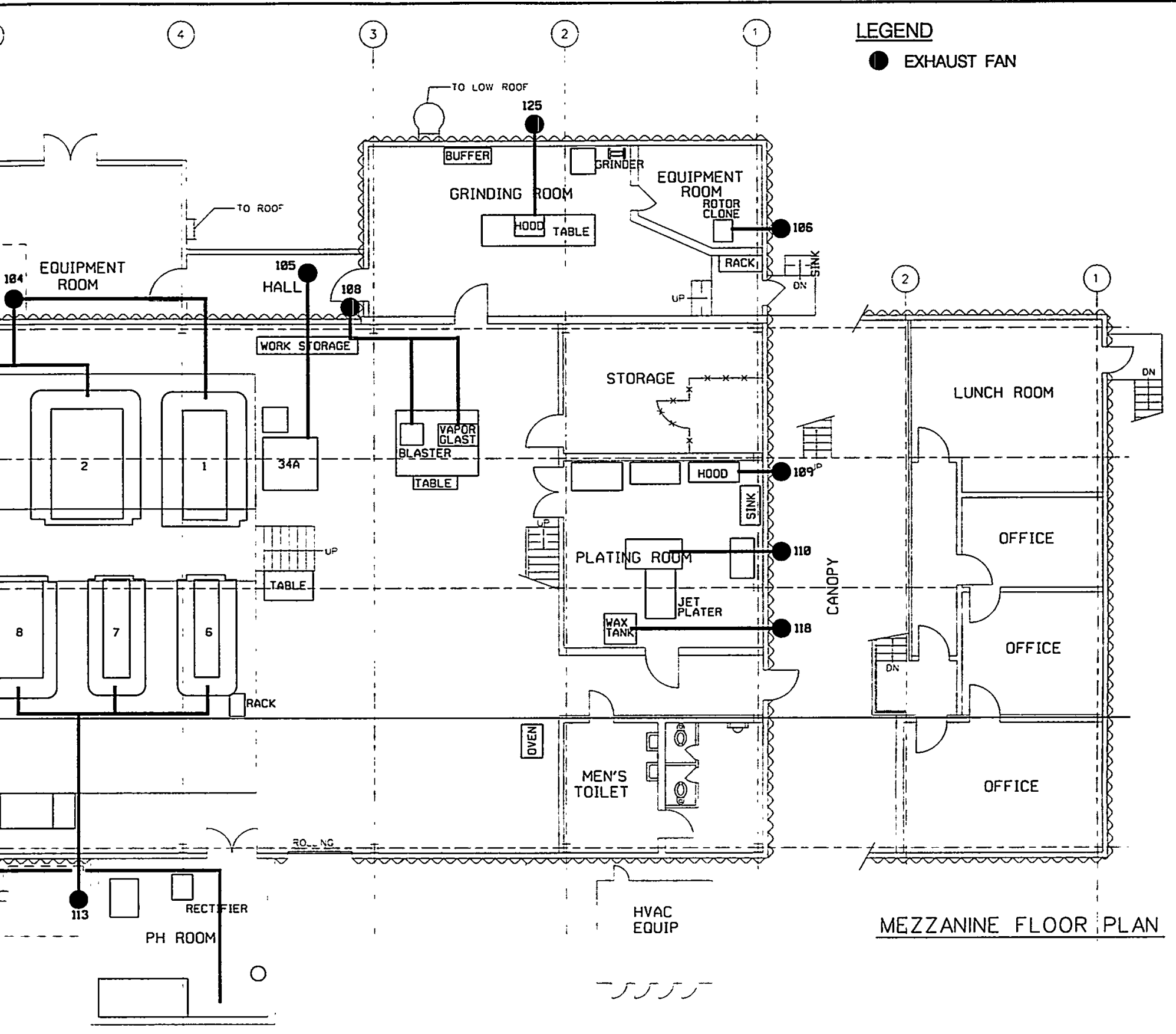

OR PLAN

VG 9401-2

AYOUT \& EXHAUST

FIGURE 1 
penetrations are at a minimum. Two bridge cranes with approximately 18 - $\mathrm{ft}$ clearance run east to west and north to south. The building's inside floor plan is $52 \mathrm{ft}$ wide by $150 \mathrm{ft}$ long clear span, with the cranes spanning the $52 \mathrm{ft}$.

The General Plating Facility was a nonradiological shop supporting the following plating/coating processes:

- acid copper

- acid zinc

- alodine coating

- aluminum anodizing and dyeing

- black oxide

- chromate conversion

- chrome plating

- electroless nickel plating

- nickel plating

- stainless steel passivation

Other operations included:

- alkaline cleaning

- masking

- pickling

- surface polishing

- waste handling

Cyanide plating operations were discontinued at the shop in the 1980 s and all cyanide compounds were removed from the building. Items, equipment, and materials that remain in the plating shop after completion of deactivation activities are listed in Table 1.

\subsection{Surveillance Activities}

The endpoint for a deactivated building is reduced $S \& M$ and maintaining the building in a safe and environmentally compliant state. Quarterly surveillances of the plating shop are necessary to ensure that unfavorable conditions or trends are identified and that remaining life safety systems are operable with no observed degradation. Building surveillances involve visual checking for indications of structural defects, roof deterioration, posting deficiencies, suspect hazardous materials, hazardous conditions, failed lights, standing water, and animal or insect intrusion. Life safety systems, such as sprinklers, game well alarms, and emergency lights and exits are included in the quarterly surveillances conducted by Y-12 support organizations. The life safety systems are tested for operability and repairs are made as required. A layout of the inspection route and life safety equipment configuration is shown in Figure 2. 
Table 1. Remaining Items, Equipment, and Materials, Building 9401-2

\begin{tabular}{|c|c|}
\hline Location & Item/Material Remaining \\
\hline Tank exhausts, and building exhaust ductwork & Residuals (see Appendix B) \\
\hline Outside tanks (1122-0466 \& 1152-0015) in dike 9500-0036 & Piping to outside tanks may contain residuals \\
\hline First floor east of platform & RadCon RMA for misc. metal fixture with fixed contamination \\
\hline First floor east of platform & Production parts \\
\hline First floor east of platform & Nickel process equipment with exchange columns Y268405 \\
\hline First floor east of platform & Work tables with attached clamps and fixtures \\
\hline First floor east of platform & Locked respirator storage cabinet \\
\hline First floor east of platform & Speedomax recorder M-82546 \& Y225413 \\
\hline First floor east of platform & Misc. metal plating fixtures, hoses, pumps, blotter paper, fans, Toledo scale, and safe M-129938 \\
\hline First floor northeast of platform & - \\
\hline Grinding room, Rm. 8 & Hood No.5 \\
\hline Grinding room, Rm. 8 & Work tables (2) with vises \\
\hline Platform & Misc. plating tanks: fiberglass, stainless steel, brick lined, etc. - empty \\
\hline Platform & Misc. hoses, electrical supply units, electrical cables, and breathing air station \\
\hline First floor restroom & Drum of urea, chemical ice chaser \\
\hline First floor restroom & Lavatories, toilet fixtures, and water heater (disconnected) \\
\hline First floor next to restroom \& second floor break room & Two water coolers, coolant remains \\
\hline Second floor office and break rooms & Two air conditioners, coolant remains \\
\hline Second floor office and break rooms & Tables, chairs, desks, bookshelves, safes, misc. office supplies \\
\hline Second floor office, $\mathrm{Rm} .3$ & Misc. nuts, bolts, washers and fittings (brass, titanium, etc.) in cabinet, tool \& die set, safes, and TV \& videocassette player Y210404 \\
\hline Annex storage area, storage room, first floor east of platform & Electrical power supplies and misc, electrical components \\
\hline Annex storage area, NRMMA & Non-RCRA chemical waste awaiting Waste Management Organization shipment off-site \\
\hline Lab, Rm. 6 & Two hoods Nos. $1 \& 3$ \\
\hline Lab, Rm. 6 & Two work tables \\
\hline pH room, Rm. 9 & Two work tables \\
\hline Outside building & Empty drums \\
\hline Outside building & Used Filters \\
\hline Outside building - north side & Storage tanks - empty \\
\hline Outside building - south side & Unused plating tanks \\
\hline \multicolumn{2}{|l|}{ EQUIPMENT: } \\
\hline Spanning platform & Bridge cranes: serial No. $3980-4$ ton; serial No. $3979-2$ ton \\
\hline South side of platform & Monorail $1000 \mathrm{lb}$, No. 3158-1159 \\
\hline West side of platform to chemical storage annex & Monorail 2 ton, No. 3158-1149 \\
\hline First floor east of platform & Vapor blaster (2 glove boxes) Tanks 33A, Y225335 and 33B, Y225334 \\
\hline West annex chemical storage area & Quincy oven, Y-219437 and one pallet ceramic heating element \\
\hline First floor east of platform & Despatch Oven Co. oven, Y-161961 \\
\hline Grinding room, Rm. 8 & Drill press, Y225356 \\
\hline Grinding room, Rm. 8 & Saw, serial No. 457-86397 \\
\hline Grinding room, Rm. 8 & Grinder \\
\hline Grinding room, Rm. 8 & Buffer \\
\hline Inside grinding room, $\mathrm{Rm} .13$ & Roto Clone, Y225323 \\
\hline pH room, Rm. 9 & Rectifier, Y172919, serial No. 9834 \\
\hline Lab, Rm. 6 & Wax processor containing wax, Tank 51-C with hood No. 2 \\
\hline
\end{tabular}




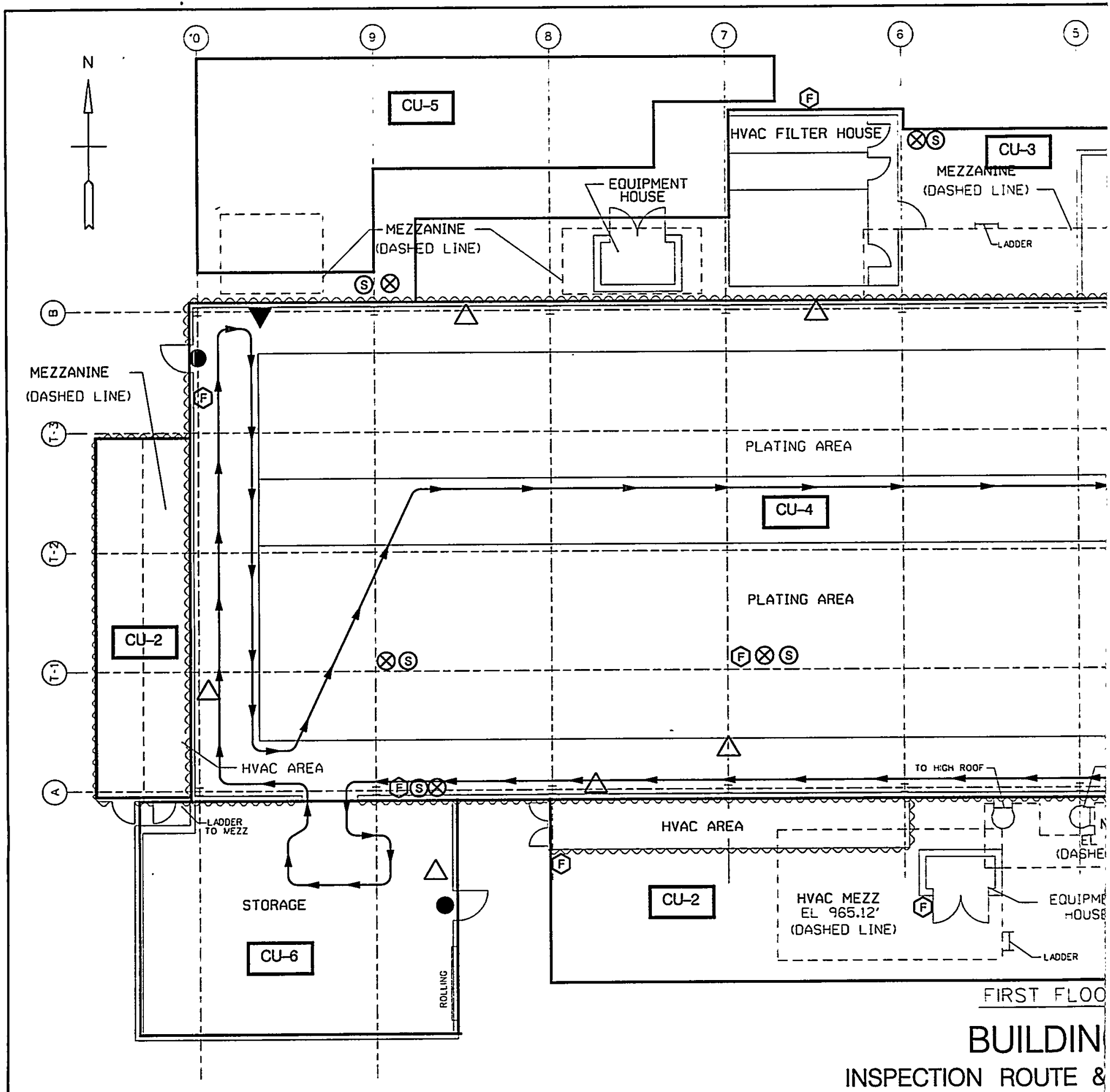

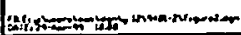

... \dgn\y-12\9401-2\figure2.dgn Apr. 29, 1999 10:01:34

Figure 2. Building 9401-2, Inspection Route and Life Safety Equipment 
6

(3)

(2)

$5^{\circ-0.62805}$
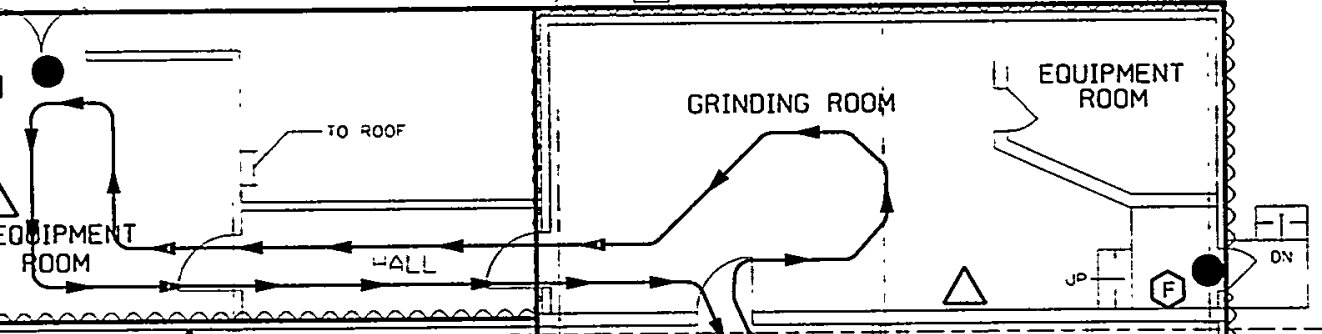

(S)

(S)

Q (B)
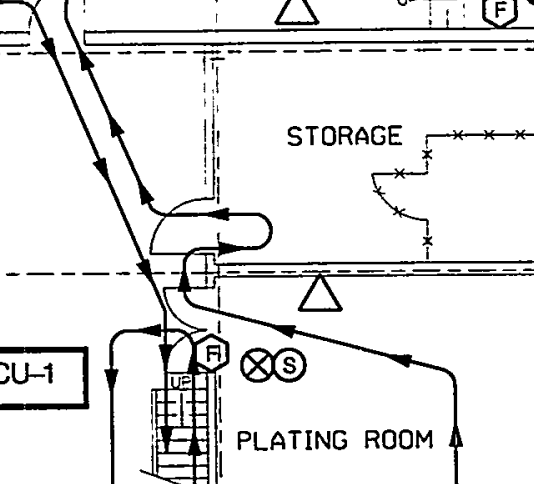

PLATING ROOM

PIA.V

9401-2

LIFE SAFETY EQUIPMENT

FIGURE 2

LEGEND

A ALARM BOX

$\triangle$ EMERGENCY LIGHT

(1) EXIT LIGHT

(E) FIRE EXTINGUISHER

$\otimes$ SAFETY EYE WASH

(s) SAFTEY SHOWER

(T) TELEPHONE

(2)
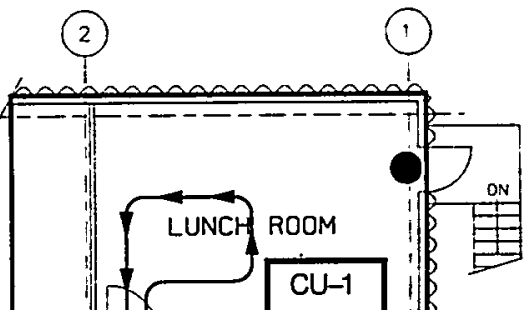

(5)

5.12

INE) PH Room $\triangle$
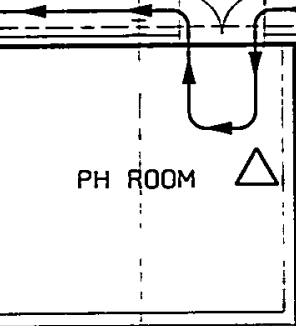

)

.

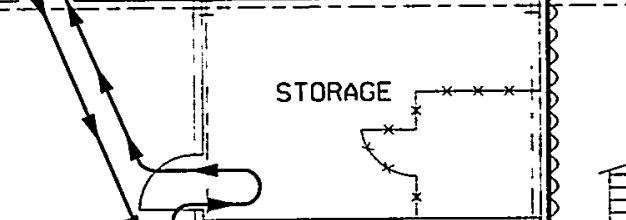

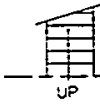
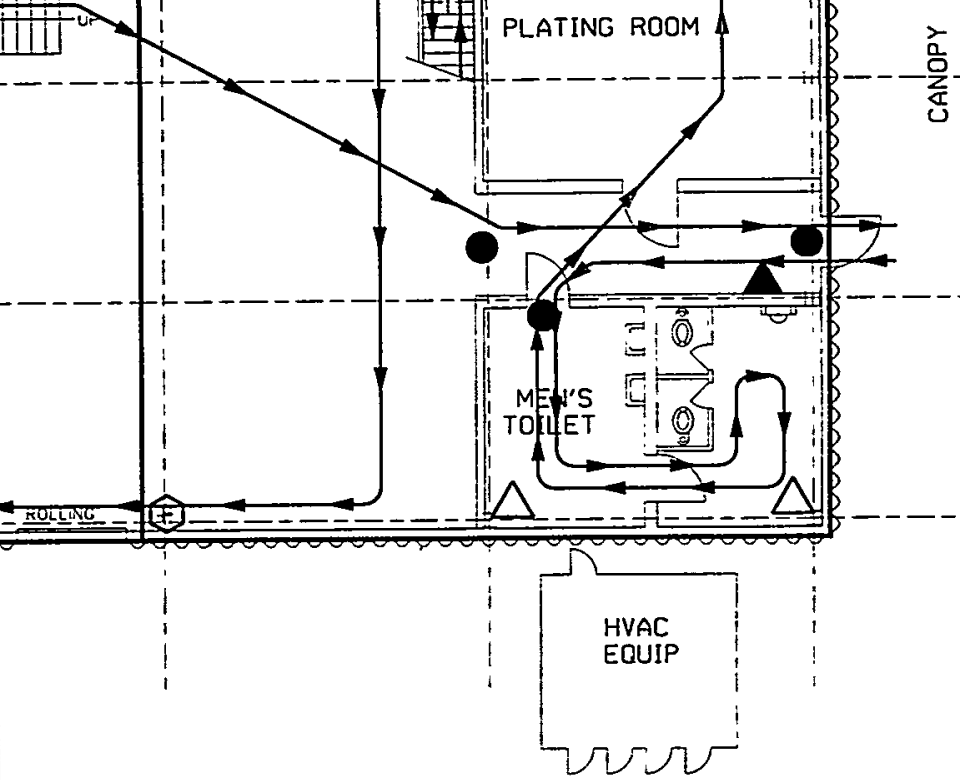

MEZZZANINE FLOOR PLAN 
Routine surveillances, monthly and weekly, governed by Operations are performed in addition to quarterly surveillances to ensure adequate operation and monitoring. During severe weather conditions such as snow, heavy rains, or when outside air temperatures fall below freezing, daily inspections of the facility are necessary to ensure that life safety systems are operable, structural integrity is maintained, and no environmental impacts have occurred. DUO round sheets for the plating shop are maintained in the plating shop building supervisor's office in Building 9201-5.

Refer to Section 11 of this document for a summary of the ongoing schedule of surveillance and maintenance activities for the building, including frequency and responsible organizations. Section 12 lists recommendations that would further reduce the required number of surveillances, which would reduce the costs of the S\&M Program. 


\subsection{FACILITY MAINTENANCE}

The building manager is responsible for all activities in the facility and for ensuring that adequate controls are provided for all work performed by the maintenance organization. Work is authorized by the building manager prior to its initiation. All Facilities Management Organization (FMO) maintenance work performed at the Y-12 Plant will be in accordance with maintenance program policy procedure Y12-015, Conduct of Operations and Maintenance (LMES, 1998b).

With the Plating Shop in the existing deactivated state, maintenance and utilities S\&M support is required to perform the following inspections:

\begin{tabular}{|l|l|l|}
\hline \multicolumn{1}{|c|}{$\begin{array}{c}\text { Responsible } \\
\text { Organization }\end{array}$} & \multicolumn{1}{c|}{ Inspection Activity } & \multicolumn{1}{c|}{ Frequency } \\
\hline $\begin{array}{l}\text { Facilities Management } \\
\text { Organization, Building } \\
\text { 9204-2 personnel }\end{array}$ & $\begin{array}{l}\text { Breaker room - breakers on recall } \\
\text { program for preventive maintenance }\end{array}$ & 5-year recall program \\
\hline $\begin{array}{l}\text { Facilities Management } \\
\text { Organization, Building } \\
\text { 9204-2 personnel }\end{array}$ & Emergency lights and exit doors & Quarterly \\
\hline Utilities & $\begin{array}{l}\text { Building interior and exterior - two } \\
\text { steam pressure reducing stations, } \\
\text { temperature and pressure, fans, and } \\
\text { steam coils }\end{array}$ & $\begin{array}{l}\text { Nonthly } \\
\text { falls below freezing }\end{array}$ \\
\hline Utilities & $\begin{array}{l}\text { Heating and ventilation filter } \\
\text { change-out }\end{array}$ & Annually \\
\hline
\end{tabular}

Preventive maintenance (PM) is required for the electrical breakers for the building. PM is performed in accordance with procedure Y18-194, Preventive Maintenance (PM) Program (LMES, 1998c). Maintenance test and checkout of the emergency and exit lights is performed in accordance with procedure Y18-002, Emergency and Exit Lighting Equipment Testing and Maintenance (LMES, 1998d).

\subsection{Planning And Coordination Of Maintenance}

Work planning and preparation for repairs, routine maintenance, or those activities discussed in Section 12 requiring FMO support is conducted in accordance with procedure Y10-012, Hazard Identification Planning for Maintenance and New Work Tasks (LMES, 1998e). This provides the process for identifying health and safety hazards associated with the work activity as well as determining the appropriate planning requirements.

\subsection{Modification Work}

Facility modification work, including temporary modifications, is accomplished under the same basic administrative controls as those applied to facility maintenance activities. The 
administrative controls help to minimize the risk to facility equipment, environment, and/or personnel. If the activity involves a modification or a temporary modification, evaluate modifications in accordance with procedure Y10-187, Integrated Safety and Change Control Process (LMES, 1998f). Evaluate temporary modifications in accordance with procedure Y10153, Temporary Modification Control (LMES, 1998g).

Modifications are performed in accordance with requirements and limitations of applicable procedures, codes, standards, and specifications.

\subsection{Seasonal Facility Requirements}

Measures must be taken to prevent damage or degradation to systems as a result of extreme weather conditions. All currently operable heaters are to be maintained and inspected to insure an inside temperature above freezing. Since there is no historical data for the building in a deactivated state, the building manager will monitor the temperature effects and make thermostat adjustments as needed.

When the outside temperature falls below freezing, Utilities personnel will perform nightly inspections of the steam system and look for off-normal conditions in the building. 


\subsection{QUALITY ASSURANCE}

The Plating Shop complies with the quality assurance program as required by DOE Order 5700.6C, Quality Assurance (1991). Support organizations as well as DUO who support or perform work in the facility are subject to the requirements of procedures Y10-202, Rev. 1, Integrated Safety Management Program (LMES, 1998a), QA-312, Rev. 1, Issues Management Program (LMES, 1997), and QA-331, Lessons Learned Program (LMES, 1998h), as integral parts of the program implementation. 


\subsection{TRAINING AND QUALIFICATION}

For entry into the Plating Shop, the following training and requirements shall be current:

- General Employee Training (GET).

- Personnel performing S\&M inspections or work shall have a DOE level-Q clearance. The building manager shall be notified for access information and access requirements.

- The requirements listed above are the minimum needed to perform no hands-on activities in the Plating Shop.

- The requirements to perform hands-on S\&M activities are specified in work packages, work procedures, and any other documented instructions. The building manager shall review, approve, and coordinate all work performed in the building. 


\subsection{ENVIRONMENTAL COMPLIANCE/PROTECTION}

The Environmental Protection (EP) program ensures safe operation of a facility is consistent with environmental and DOE requirements, controls, and standards. During surveillance, EP is implemented in the Plating Shop facility activities identified in Section 2, "Facility Activities," as described below.

During the Plating Shop deactivation project, chemicals and wastes were removed, excessed, or disposed to meet the DOE deactivation performance measures for a safe and environmentally compliant building. This included flushing and removal of hazardous solutions from the plating tanks, removal of hazardous chemicals from storage, and abatement of asbestos-contaminated residue located in the diking underneath the plating tanks. All Satellite Accumulation Areas and RCRA 90-day Accumulation Areas have been closed. Chemicals remaining in the facility are packaged for shipment through the Waste Management Organization for off-site disposal. Table 1, of Section 2.2, "Facility Description" lists items, equipment, and materials that remain in the Plating Shop.

The Plating Shop maintains an outside dike, No. 9500-0099, located on the northwest side of the building, which was used as a secondary containment for waste storage during operations and deactivation activities. The dike contains an electric sump pump. Operations personnel inspect the dike on a weekly basis or more frequently in the event of rain or precipitation that may cause collection of water in the dike as required by procedure Y70-909, Dike Management (LMES, 1996). The Y-12 Environmental, Safety and Health Organization performs a visual inspection of the dike annually and samples the water that collects in the dike for approval, prior to Operations personnel pumping the water to the ground. The Y-12 Equipment, Test, and Inspection (ET\&I) group also performs a visual inspection and/or hydrostatic leak test as part of a plantwide dike inspection program per procedure Y50-55-EI-013, Inspection and Testing of Dikes (LMES, 1995b). The ET\&I visual inspection of the dike is performed every 3 years. It is recommended that the pump be removed and the dike be filled and capped. Breaching the dike will eliminate dike inspections by three organizations as well as removing the need for sampling and pumping rainwater that collects in the dike.

Dangerous or hazardous waste is not expected during S\&M activities. However, waste generated from routine maintenance is handled in compliance with the applicable regulatory requirements and plant procedures for waste handling and disposition. Abnormal conditions are reported and documented and corrective actions are initiated through the inspections required during S\&M. 


\subsection{Plating Shop, Building 9401-2 Air Permit}

The exhausts for the Plating Shop were permitted under the Tennessee Department of Environment and Conservation, Y-12 Plant Operating Permit, State Reference Number 01-002088. Since plating operations have ceased and exhausts de-energized, a request by the DUO organization has been submitted to the Y-12 Plant Environmental Safety and Health Organization requesting removal of Plating Shop exhausts from the Y-12 Plant active air permit.

\subsection{Regulatory Files/Documentation}

Regulatory documentation for RCRA-managed areas has been filed in the Y-12 Environmental, Safety and Health organization offices. Waste disposal forms (UCN-2109 forms) for treatment, storage, or disposal of wastes generated during the deactivation activities and dispositioned through the Waste Management Organization (WMO) are located in the WMO Record Copy Files, Building 9624. 


\subsection{RADIOLOGICAL CONTROLS}

The Plating Shop is a nonradiological shop. Two RMAs were established during deactivation activities. The RMA located outside the building at dike No. 9500-0099 was established for acceptance of rad-contaminated waste transport containers, such as tuff-tanks and tankers for wastewater treatment. The second RMA is located inside the Plating Shop east of the plating platform and contains miscellaneous metal items (small scales, file cabinet, and metal shelving) that were found to have fixed rad-contamination. A quarterly inspection of the RMAs is performed by the Radiological Control (RadCon) group to ensure correct postings and check readings in the area. The procedure governing the RadCon survey is Y75-56-FO-107, Workplace Contamination and Radiation Surveys (LMES, 1998i). Operations personnel are required by procedure Y75-101, Transfer and Management of Material for Radiological Control (LMES, 1998j), to conduct a check of the RMAs as part of the facility walkthrough. It is recommended that metal items be placed into a Department of Transportation (DOT)-approved waste container for waste disposal and both RMAs be downgraded to eliminate the required inspections by RadCon and Operations personnel.

The Plating Shop has an established Non-Radioactive Material Management Area (NRMMA), the west annex chemical storage area, that contains chemicals packaged and labeled for off-site shipment through the Waste Management Organization. When the building is no longer used for storage, eyewash stations and safety showers can then be removed, eliminating inspection and risk of freeze damage. 


\subsection{EMERGENCY MANAGEMENT}

The following actions have been taken to facilitate Emergency Management measures for Building 9401-2 during S\&M. If an emergency occurs at the Plating Shop, the response to mitigate would fall under the Y-12 Plant Emergency Preparedness Program.

\subsection{Emergency Preparedness}

The building is to be locked and unoccupied except for entries into the building by surveillance personnel during routine inspections or planned maintenance. Access control is the responsibility of the DUO building manager. Prior to nonroutine entries into Building 9401-2, the building manager shall brief personnel on the specific entry requirements and equipment.

An inspection round sheet ensures that surveillance personnel inspect all areas of concern. Figure 2 outlines the interior inspection route for the Plating Shop. Doors have been locked with crash bars for easy exit in case of an emergency. Fire protection equipment (sprinklers and fire extinguishers) remain in service inside the building and are identified in Figure 1. There are nine fire extinguishers remaining inside the building and three remaining outside the building. Six active safety showers and six eyewash stations remain inside the building. Two active safety showers and three eyewash stations remain outside the building. Monthly inspections shall be performed by Operations personnel on the fire extinguishers, safety showers, and eyewash stations even though the building is listed as inactive. The regulation governing the monthly inspection of the fire extinguishers is ESS-FO-101, Fire Extinguisher Maintenance (Martin Marietta Energy Systems (MMES), 1992), and FP-105PD, Rev. 0, Fire Protection Program (LMES). As a best management practice, Operations perform weekly inspections on the safety showers and eyewash stations to ensure rust has not restricted water flow. The procedure covering the safety eyewash and safety showers is Y73-059PD, Emergency Eyewash and Shower Equipment (LMES, 1998k). When the building is no longer used for storage, loose combustibles have been removed throughout the building, access control is in place, and DOE concurs, then all fire extinguishers may be removed from the building. A fire extinguisher will be required at the entrance to the building for surveillance personnel. Safety showers and eyewash stations may also be disconnected when the building is no longer used for storage which would reduce the potential for freeze damage. Removing the fire extinguishers, safety showers, and eyewash stations would eliminate eight safety showers, nine eyewash weekly and monthly inspections, eight monthly fire extinguisher inspections, reduce the risk of freeze damage, and thus reduce S\&M cost.

DUO personnel perform monthly inspections of facility emergency lights and exit doors to ensure that they function properly in accordance with plant procedure FP-105PD, Rev. 0 (LMES). FMO, Building 9204-2 personnel perform a quarterly inspection of the emergency lights and exit doors. It is recommended to discontinue the quarterly inspections of the emergency and exit lights by FMO Building 9204-2 personnel since Operations personnel are conducting monthly checks. FMO personnel will continue to make needed repairs as requested by Operations. 


\subsection{Emergency Response}

If an emergency or abnormal incident occurs during $S \& M$ activities, personnel shall evacuate to Assembly Station No. 9, northeast of the building and notify the PSS office (574-7172). Gamewell boxes are located at the doors at both the east and west ends of the building. The Emergency Notification System (ENS) will remain in operation until further deactivation has been accomplished. The ENS will require annual inspections by Operations personnel as required by procedures 29 CFR 1910.165, Employee Alarm Systems (Code of Federal Regulations (CFR)), and Y10-003, Plant Public Address and Emergency Notification Systems (LMES, 19981). Surveillance of the Public Address (PA)/ENS requires personnel to be in the building during set times, per procedure Y10-003 (LMES, 19981), when announcements are conducted over the Y-12 Plant PA/ENS. For a list of all inspections, refer to Table 2, Section 11. 


\subsection{HEALTH \& SAFETY}

\subsection{Fire Hazard Analysis}

A Fire Hazard Analysis (FHA) has not been performed at this time. An FHA will be completed per DOE Order 420.1, Facility Safety (1995), to assess the fire risks that may remain at the inactive facility and to confirm there are no undue fire hazards to site personnel and the public.

\section{$9.2 \quad$ Fire Protection}

Building 9401-2 is covered under the Y-12 Plant Fire Protection Program. Fire protection systems in the Plating Shop are being maintained as part of S\&M. A wet pipe sprinkler system is active in the building, covering the main plating area and second floor offices and breakroom. The sprinkler system within the plating tank exhaust ductwork has been deactivated as part of the deactivation activities. Combustible-type chemicals packaged for off-site waste disposal have been moved to the main plating shop floor per direction from the Fire Protection organization. The sprinkler system in the chemical storage annex has not been in operation since being removed from service prior to deactivation activities.

The Fire Department performs a monthly visual inspection of the sprinkler system, and a semiannual sprinkler system main drain and alarm test (MMES, 1992b). Bimonthly building inspections are also conducted by the Fire Department to ensure that no materials have been moved into the building which could compromise the existing conditions or create fire hazards. The Fire Department performs an annual inspection of the two building Gamewell boxes. These Gamewell boxes are located at the east and west doors of the building.

Nine fire extinguishers inside the building and three outside the building remain in service. The Fire Department inspects all the fire extinguishers annually while monthly checks are made by Operations personnel. The regulation governing the monthly inspection of the fire extinguishers is ESS-FO-101, Fire Extinguisher Maintenance (MMES, 1992a), and FP-105PD, Rev. 0, Fire Protection Program (LMES). When the building is no longer used for storage, loose combustibles have been removed throughout the building, access control is in place, and DOE concurs, then all fire extinguishers may be removed from the facility. A fire extinguisher will be required at the entrance to the building for surveillance personnel.

\subsection{Occupational Safety And Health}

The DUO Organization is responsible for managing, organizing, and maintaining control of S\&M activities at Building 9401-2. Even though the inactive facility is classified as "Industrial/Nonnuclear" and in a stable state, the Nuclear Operations Conduct of Operations methodology will continue to be implemented to ensure $S \& M$ activities are performed within the established safety envelope that remains for the facility. Conduct of Operations requirements specific to the DUO Organization are in accordance to Appendix III of the Nuclear Operations Conduct of Operations Manual (LMES, 1999). S\&M activities for the facility will be conducted 
in a manner that maintains the safety envelope, meets the environmental requirements, and provides safe and efficient work practices.

The Occupational Safety and Health Administration (OSHA) regulation in Title 29 of the CFR, Parts 1910 and 1926, applies to DOE contractor and subcontractor employees and facilities at the Y-12 Plant. These OSHA requirements are mandated by DOE Order 440.1A, Worker Protection Management for DOE Federal and Contractor Employees (1998b), and DOE 5480.4, Environmental Protection, Safety, Health Protection Standards (1984), and are considered the minimum acceptable standards for implementation.

The OSHA standards pertinent to the S\&M of an inactive facility are 29 CFR 1910, Occupational Safety and Health Standards, and 29 CFR 1926, Safety and Health Regulations for Construction. The requirements of 29 CFR 1910 are applicable to the routine activities conducted by S\&M personnel, whereas 29 CFR 1926 requirements are applied to construction, modification, or demolition work that is subject to the Davis-Bacon Act. 


\subsection{SAFEGUARDS AND SECURITY}

Currently, the Plating Shop, Building 9401-2, is classified as an "Industrial/Nonnuclear" facility. No Special Nuclear Materials or precious metals are stored in the building. There are no active intrusion alarms or other building conditions that require routine security checks. The stored surplus parts do not require security protection; however, it is recommended that the parts be removed to another location for long-term storage prior to decontamination and decommissioning (D\&D) of the building. 


\subsection{SURVEILLANCE AND MAINTENANCE ACTIVITIES}

The current condition of the Plating Shop warrants inspection by several organizations. Table 2 identifies the responsible organization, frequency of inspection, and the requirement driving the inspection. Each respective section of this plan further explains the need for these surveillances.

Table 2. Surveillance and Maintenance Activities Schedule, Building 9401-2

\begin{tabular}{|c|c|c|c|}
\hline $\begin{array}{l}\text { Responsible } \\
\text { Organization }\end{array}$ & Inspection Activity & Frequency & Requirement \\
\hline Fire Department & Fire extinguishers & Annually & ESS-FO-101 \\
\hline \multirow[t]{2}{*}{ Fire Department } & \multirow[t]{2}{*}{ Sprinklers } & Monthly & FP-105PD \\
\hline & & Semi-Annually & $Y-50-50-301$ \\
\hline Fire Department & Building & Bi-Monthly & FP-105PD \\
\hline Fire Department & Gamewell alarms & Annually & FP-105PD \\
\hline Operations Personnel & $\begin{array}{l}\text { Emergency notification } \\
\text { system/public address } \\
\text { system }\end{array}$ & Annually & $\mathrm{Y} 10-003$ \\
\hline Operations Personnel & Fire extinguishers & Monthly & $\begin{array}{l}\text { ESS-FO-101 } \\
\text { FP-105PD }\end{array}$ \\
\hline Operations Personnel & $\begin{array}{l}\text { Emergency lights and exit } \\
\text { doors }\end{array}$ & Monthly & FP-105PD \\
\hline Operations Personnel & Eyewash \& safety showers & $\begin{array}{l}\text { Weekly and } \\
\text { Monthly }\end{array}$ & $\begin{array}{l}\text { Best-Management } \\
\text { Practice, Y73-059 }\end{array}$ \\
\hline Operations Personnel & Interior dike & Weekly & Best Management Practice \\
\hline \multirow[t]{2}{*}{ Operations Personnel } & \multirow{2}{*}{$\begin{array}{l}\text { Dike } 9500-0099 \text { and old } \\
\text { cyanide tank }\end{array}$} & Weekly & \multirow[t]{2}{*}{ Y70-909 } \\
\hline & & $\begin{array}{l}\text { As needed: water } \\
\text { collection/pumping }\end{array}$ & \\
\hline \multirow{2}{*}{ Operations Personnel } & \multirow{2}{*}{$\begin{array}{l}\text { Building interior \& exterior } \\
\text { - general walkthrough for } \\
\text { RMA inspection, } \\
\text { water/leaks/degradation of } \\
\text { structure \& roof } \\
\end{array}$} & Quarterly & Y75-101 \\
\hline & & $\begin{array}{l}\text { Daily: severe } \\
\text { weather or outside } \\
\text { air temperature } \\
\text { falls below freezing }\end{array}$ & DOE O 430.1A \\
\hline \multirow{2}{*}{$\begin{array}{l}\text { Y-12 Environmental, } \\
\text { Management } \\
\text { Department }\end{array}$} & \multirow[t]{2}{*}{ Dike 9500-0099 } & Annually & \multirow[t]{2}{*}{ Y70-909 } \\
\hline & & $\begin{array}{l}\text { As needed: sample } \\
\text { collection }\end{array}$ & \\
\hline \multirow[t]{2}{*}{$\begin{array}{l}\text { Equipment Test \& } \\
\text { Inspection group }\end{array}$} & \multirow[t]{2}{*}{ Dike 9500-0099 } & $\begin{array}{l}\text { 3-year visual } \\
\text { inspection }\end{array}$ & \multirow[t]{2}{*}{ Y50-55-EI-013 } \\
\hline & & $\begin{array}{l}\text { Periodically: } \\
\text { hydrostatic leak test }\end{array}$ & \\
\hline $\begin{array}{l}\text { Facilities } \\
\text { Management } \\
\text { Organization, } \\
\text { Building 9204-2 } \\
\text { personnel } \\
\end{array}$ & $\begin{array}{l}\text { Breaker room - breakers on } \\
\text { recall program for } \\
\text { preventive maintenance }\end{array}$ & $\begin{array}{l}\text { 5-year recall } \\
\text { program }\end{array}$ & Y18-194 \\
\hline
\end{tabular}




\begin{tabular}{|c|c|c|c|}
\hline $\begin{array}{l}\text { Responsible } \\
\text { Organization }\end{array}$ & Inspection Activity & Frequency & Requirement \\
\hline $\begin{array}{l}\text { Facilities } \\
\text { Management } \\
\text { Organization, } \\
\text { Building 9204-2 } \\
\text { personnel }\end{array}$ & Emergency and exit lights & Quarterly & Y18-002 \\
\hline \multirow[t]{2}{*}{ Utilities } & \multirow{2}{*}{$\begin{array}{l}\text { Building interior \& exterior } \\
\text { - two steam pressure } \\
\text { reducing stations, } \\
\text { temperature } \& \text { pressure, fans } \\
\text { and steam coils }\end{array}$} & Monthly & \multirow[t]{2}{*}{ Best Management Practice } \\
\hline & & $\begin{array}{l}\text { Nightly: outside air } \\
\text { temperature falls } \\
\text { below freezing }\end{array}$ & \\
\hline Utilities & $\begin{array}{l}\text { Heating and ventilation filter } \\
\text { change out }\end{array}$ & Annually & Best Management Practice \\
\hline $\begin{array}{l}\text { Radiological Control } \\
\text { Organization }\end{array}$ & $\begin{array}{l}\text { Radioactive Material Areas } \\
\text { (RMA) }\end{array}$ & Quarterly & Y75-56-FO-107 \\
\hline
\end{tabular}




\subsection{RECOMMENDATIONS}

The S\&M Plan incorporates DOE Order 430.1A, Life Cycle Asset Management (LCAM) (1998a) direction to provide for conducting $S \& M$ activities required to maintain the facility in a stable and known condition pending disposition.

The following recommendations have been compiled in an effort to maintain the facility in its current stable state and known condition. These recommendations will help ensure residual and stored materials are managed properly; control facility access; minimize potential hazards; comply with environmental, safety, health safeguards and security requirements; and reduce S\&M requirements and costs.

1. Cap exhaust stacks. The exhaust ductwork associated with the plating tanks has not been cleaned. Residual plating materials may be in the ductwork and could be washed into the building or leak through the ductwork outside the building.

2. Place radiologically contaminated items in a container for disposal. Removal of the items and a RadCon survey of the area will allow for downgrading the RMAs and the elimination of a quarterly inspection by RadCon.

3. Drain oil from hoists and cranes, which will remove a combustible hazard and mitigate the potential for leakage.

4. Remove air conditioning units and water fountains for reuse. If the decision is made to keep the items in place, remove the coolant for reuse to remove the hazardous material.

5. Remove or cover metal filters located outside the southeast corner of the building to strive for storm water pollution-preventive measures.

6. Evaluate heating system. If feasible, install a return air duct to the makeup air unit (MAU) located on the north side of the building and utilize $90 \%$ return air. All MAUs are currently supplying $100 \%$ outside air which is a tremendous loss of energy during the winter months.

7. Place a permanent cap on the outside cyanide tank or remove the tank to prevent potential collection of rainwater.

8. Remove combustibles from the second floor office, breakroom, and storage areas and expedite removal of waste chemicals from the NRMMA. When these areas are emptied, the building will no longer be used for storage. All eyewash and safety showers can then be removed, eliminating inspection requirements and risk of freeze damage; only one fire extinguisher will then be required. The one remaining extinguisher will be located outside the main entrance on the east side of the building. Inspections and maintenance can be discontinued for all other extinguisher units. The building manager is responsible 
for ensuring all combustible materials within the building are kept to a minimum or removed when not required in accordance with procedure FP-105PD, Rev. 0, Fire Protection Program (LMES).

9. Identify existing fire extinguisher locations with appropriate markings per procedure Y70-251, Fire Protection Equipment and Identification (LMES, 1998m).

10. Obtain DOE concurrence to deactivate heat sensors and associated alarm after completion of the Fire Hazard Analysis (FHA). The plating solutions have been removed from the building and the building sprinkler system remains active. The need for the alarm to be activated at the Plant Shift Superintendent office will no longer be necessary. Fire Protection Engineering will perform the FHA, which will determine whether this action is acceptable to pursue.

11. Post entry requirements at the main entrance and have door locks repaired that are not operational. Control of building access is necessary to prevent unauthorized storage and unplanned work.

12. Incorporate the following entry requirements into the main entrance posting: ensure twoperson rule; notify the Plant Shift Superintendent (PSS) before and after entry into the facility, and maintain emergency communication, such as a two-way radio or portable telephone during entry. Per PSS recommendation, implementing these entry actions will eliminate the need for PA/ENS requirements.

13. Cleanup debris in various locations of the interior and exterior of the building to promote good housekeeping. Ensuring that good housekeeping practices are enforced is required by the building manager as stated in procedure FP-105PD, Rev. 0 (LMES).

14. Shut off building exhaust. Industrial Hygiene has determined that the system is not required to be in operation for entry into the building.

15. Remove all conflicting or unnecessary signage in the building and on the plating tanks.

16. Seal building openings to help control potential entry from vermin. The presence of vermin is more likely in a building with minimal activity.

17. Breach tanker dike 9500-0099. De-energize and remove the sump pump before filling and capping the dike. This will eliminate dike inspections as well as the need for sampling and pumping rainwater that collects in the dike.

18. Remove metals such as copper, brass, metal storage cabinets, etc. located in the second floor office, breakroom, and storage areas. This will promote good housekeeping and eliminate potential unauthorized storage locations. After RadCon has surveyed and green-tagged each item, the metals can be shipped to scrap metal recycle. 
19. Disconnect outside process lines at tanks Numbers 1122-0466 and 1152-0015; both tanks are empty. Flush the process lines to remove any residual material and cap the ends. Labeling each flushed pipe to reflect the final status will eliminate any uncertainty of material hazards to personnel removing the piping in the future.

20. Remove stored surplus production parts from the building to another location for longterm storage.

21. Discontinue quarterly inspections of the emergency and exit lights by FMO (Building 9204-2 personnel), since Operations personnel are already conducting monthly checks. FMO personnel will continue to make needed repairs.

22. Discontinue weekly inspection of the platform dike inside the building. Incorporate the dike inspection into the quarterly walkthrough and during severe weather. 


\subsection{REFERENCES}

29 CFR 1910. Occupational Safety and Health Standards.

29 CFR 1910.165. Employee Alarm Systems.

29 CFR 1926. Safety and Health Regulations for Construction.

DOE. 1984. Order 5480.4, Environmental Protection, Safety, and Health Protection Standards.

. 1991. Order 5700.6C, Quality Assurance.

. 1995. Order 420.1, Facility Safety, Sect. 4.2, "Fire Protection."

. December 1997. G430.1A-2, Surveillance and Maintenance During Facility Disposition.

. October 1998a. Order 430.1A, Life Cycle Asset Management (LCAM).

- 1998b. Order 440.1A, Worker Protection Management for DOE Federal and Contractor Employees.

LMES. January 17, 1991. HS/21/F/6, Phase I Hazard Screening Analysts for Plating and Surface Coating Operations at Buildings 9201-5N, 9204-4, and 9401-2.

- July 11, 1995a. Memo, T. R. Butz to D. P. Bryant et al., Approval of the 1027-92 Hazard Categorizations.

. August 1995b. Y50-55-EI-013, Inspection and Testing of Dikes.

. October 1996. Y70-909, Dike Management.

. June 1997. QA-312, Rev. 1, Issues Management Program.

. June 1998a. Y10-202, Rev. 1, Integrated Safety Management Program.

. October 1998b. Y12-015, Conduct of Operations and Maintenance.

. October 1998c. Y18-194, Preventive Maintenance (PM) Program.

. September 1998d. Y18-002, Emergency and Exit Lighting Equipment Testing and Maintenance.

. June 1998e. Y10-012, Hazard Identification Planning for Maintenance and New Work Tasks. 
. March 1998f. Y10-187, Integrated Safety and Change Control Process.

. March 1998g. Y10-153, Temporary Modification Control.

. September 1998h. QA-331, Lessons Learned Program.

. December 1998i. Y75-56-FO-107, Workplace Contamination and Radiation Surveys.

. August 1998j. Y75-101, Transfer and Management of Material for Radiological Control.

. November 1998k. Y73-059PD, Emergency Eyewash and Shower Equipment.

. May 19981. Y10-003, Plant Public Address and Emergency Notification Systems.

. August 1998m. Y70-251, Fire Protection Equipment and Identification.

. January 1999. Nuclear Operations Conduct of Operations Manual, Appendix III.

. No date. FP-105PD, Rev. 0, Fire Protection Program.

MMES. November 1992a. ESS-FO-101, Fire Extinguisher Maintenance.

. December 1992b. Y50-50-301, Semi-annual Sprinkler System Main Drain and Alarm Test. 
APPENDIX A.

DEACTIVATION ACTION ITEM SUMMARY FOR BUILDING 9401-2 


\begin{tabular}{|c|c|c|c|}
\hline $\begin{array}{l}\text { Item } \\
\text { No. }\end{array}$ & SAFE AND COMPLIANT ACTIONS & $\begin{array}{l}\text { Actions } \\
\text { Completed }\end{array}$ & Comments \\
\hline 1 & Remove RCRA/asbestos residue from the interior dike. & $\sqrt{ }$ & (1) \\
\hline 2 & $\begin{array}{l}\text { Drain solutions, remove solids, and verify clean the following: } \\
\text { - Plating tanks } \\
\text { - Northwest outside plating rinse water sump } \\
\text { - SID \#17 }\end{array}$ & $\sqrt{ }$ & (2), (3) \\
\hline 3 & Remove all process materials, unused chemicals, and generated waste. & $\sqrt{1}$ & (4) \\
\hline 4 & Remove all gas cylinders. & $\sqrt{ }$ & - \\
\hline 5 & Remove all contents from the acid and flammable storage cabinets. & $\sqrt{ }$ & (5) \\
\hline 6 & Remove/dispose of all flammables, loose combustibles, and oxidizers. & $\sqrt{ }$ & (6) \\
\hline$\overline{7}$ & $\begin{array}{l}\text { Label all drums and other containers per Waste Management and DOT } \\
\text { criteria for disposal or off-site shipments. }\end{array}$ & $\sqrt{ }$ & (7) \\
\hline 8 & Maintain RCRA 90-day accumulation areas until closure. & $\sqrt{ }$ & (8) \\
\hline 9 & Remove all classified materials. & $\sqrt{ }$ & - \\
\hline 10 & Remove/dispose of all contents from file cabinets, desks, and bookcases. & $\sqrt{ }$ & (6) \\
\hline 11 & $\begin{array}{l}\text { Deactivate the following: } \\
\text { - Disconnect and cap plating tank drains } \\
\text { - Disconnect process lines, including acid and water at each plating tank } \\
\text { - De-energize all power to the tank platform } \\
\text { - Shutoff and blank natural gas header to building } \\
\text { - Disconnect and blank hydrochloric and nitric acid supply lines to the } \\
\text { building } \\
\text { - Flush all acid lines located within the building and cap } \\
\text { - Rlug floor drains } \\
\text { - Remove refrigerant/freon from cooling equipment }\end{array}$ & $\sqrt{ }$ & (9) \\
\hline 12 & $\begin{array}{l}\text { De-energize and disconnect utilities to the following support equipment: } \\
\text { - Filter system } \\
\text { - } \text { Ovens (2) } \\
\text { - } \text { Srill Press } \\
\text { - Grinder } \\
\text { - } \text { Buffer } \\
\text { - Roto Clone } \\
\text { - Recitifier } \\
\text { - } \text { Glovebox/vaporblaster (2) } \\
\text { - } \text { Place "Out of Service" tags on deactivated equipment } \\
\end{array}$ & $\sqrt{ }$ & - \\
\hline 13 & $\begin{array}{l}\text { The building should not look as if it has been abandoned, but it should be in } \\
\text { an orderly condition that reflects "good housekeeping." }\end{array}$ & $\sqrt{ }$ & - \\
\hline
\end{tabular}




\section{DEACTIVATION ACTION ITEMS SUMMARY FOR BUILDING 9401-2}

\begin{tabular}{|c|c|c|c|}
\hline $\begin{array}{l}\text { Item } \\
\text { No. }\end{array}$ & SURVEILLANCE AND MAINTENANCE ACTIONS & $\begin{array}{l}\text { Actions } \\
\text { Completed }\end{array}$ & Comments \\
\hline 1 & Disconnect power to eye bath/safety shower and tag "Out of Service." & - & (10) \\
\hline 2 & $\begin{array}{l}\text { Disconnect and reroute electrical power to Building } 9727-3 \text {, Nitrogen } \\
\text { Plant. }\end{array}$ & $\sqrt{ }$ & - \\
\hline 3 & De-energize all overhead cranes and hoists and tag "Out of Service." & $\sqrt{ }$ & (11) \\
\hline 4 & $\begin{array}{l}\text { De-energize plating tank exhaust fans } \\
\text { EF } 101,102,103,104,105,106,108,109,110,113,114,115,116,117 \text {, } \\
118,119,120, \& 125 .\end{array}$ & $\sqrt{ }$ & (12), (13) \\
\hline 5 & Breach outside dikes: $9500-0035,9500-0036$ and $9500-0098$. & $\checkmark$ & (14) \\
\hline 6 & $\begin{array}{l}\text { Shut off potable water, disconnect and plug drains to sinks, toilets, and } \\
\text { water fountains. }\end{array}$ & T & - \\
\hline 7 & $\begin{array}{l}\text { Remove and cap ends of sprinkler system piping located in exhaust } \\
\text { ductwork. }\end{array}$ & $\checkmark$ & (15) \\
\hline 8 & Relocate personnel. & $\sqrt{ }$ & - \\
\hline 9 & Post an "inactive" sign at each building entry. & $\sqrt{ }$ & (16) \\
\hline
\end{tabular}

NOTE: Materials which are anticipated to be surplus to the Defense Program mission (such as equipment, parts/components, and tooling) may remain in Building $9401-2$ if they are properly managed. The long-term disposition options for these materials have not been determined at this time. The minimum expectations are that material remaining in the building will be stored in an orderly manner and managed by the building manager or DUO designee in compliance with $Y-12$ Plant policies and procedures.

The DUO designee will remain responsible for management of all waste and off-site shipments while stored at Building 9401-2. 


\section{COMMENTS}

(1) Fifty-nine drums of waste were generated and have been picked up for disposal. Dike surface was sealed after residue removal.

(2) "Clean" was defined as having no visible liquid and/or sludge. A posting signed by Environmental Management, the Operations Manager designee, and the Waste Management Coordinator was placed on each plating tank verifying no visible liquid or sludge was present.

(3) The northwest sump pump was de-energized and removed. The sump was filled with gravel and capped with concrete.

(4) Production parts will remain stored within the building per Depleted Uranium Operations (DUO) decision. Unused chemicals have been DOT-packaged, labeled, and are awaiting shipment for off-site disposal. NonRCRA waste materials will remain at the building until disposition through the Waste Management Organization (WMO).

(5) All acid and flammable storage cabinets were RadCon-monitored and picked up for scrap metal recycle. All cabinet contents were dispositioned for reuse or disposal.

(6) The office area remains functional per DUO decision. Paper-type "loose combustibles" remain in the office area. All flammables, loose combustibles, and oxidizers from the lab and process areas have been removed.

(7) Waiting on analysis for several drums so RadCon can monitor and Waste Management can pick up for disposal.

(8) There are three RCRA storage areas: AA-187, AA-188, and AA-17. Five satellite accumulation areas (SA-161, SA-189, SA-190, SA-191, and SA-565) were closed during deactivation and one area (SA-601) was closed prior to deactivation activities.

(9) The hydrochloric acid supply line to the building was fed from Building 9204-2. Personnel from Building 92042 flushed the acid line and de-energized the supply pump. The nitric acid supply line was fed from Building 9206. Personnel from Building 9206 were notified the line to $9401-2$ would be blanked off. Flushing was not conducted since the nitric acid supply line fed other facilities.

(10) Eye baths/safety showers will remain active until all waste materials and chemicals have been removed from the building and all RCRA storage areas have been closed.

(11) Lubrication oil remains in the hoists and cranes.

(12) Caps have been fabricated for each exhaust stack and are ready for installation in response to Operations' concern that heavy rains would cause a backwash through the inactive stacks into the building.

(13) The request to cancel the air permit has been initiated by DUO.

(14) Tanker dike, 9500-0099, will remain functional for future Y-12 Plant needs. DUO will be responsible for maintaining the dike until a new owner is identified.

(15) The sprinkler system located under the platform and within the plating tank ductwork was inactive and blanked off at the header in Room \#8 prior to the start of deactivation activities. The sprinkler piping was in a damaged state due to the corrosive atmosphere within the ductwork. As part of the deactivation project, maintenance removed the sprinkler piping from within the ductwork and capped each line at the header in the main plating bay. With all plating solutions removed and no future plating operations planned, the piping will not be replaced.

The building manager or DUO designee will be responsible for controlling access into the building.

General Comment: REMAINING ACTIVE SERVICES ARE: STEAM, BUILDING VENTILATION, AIR, LIGHT, BUILDING SPRINKLER SYSTEM. Surveillance and maintenance (S\&M) activities will be ongoing for these services. The building manager or DUO designee will be responsible for insuring $S \& M$ is conducted and access control is maintained on the building. 


\section{Deactivation Action Items Summary For Building 9401-2}

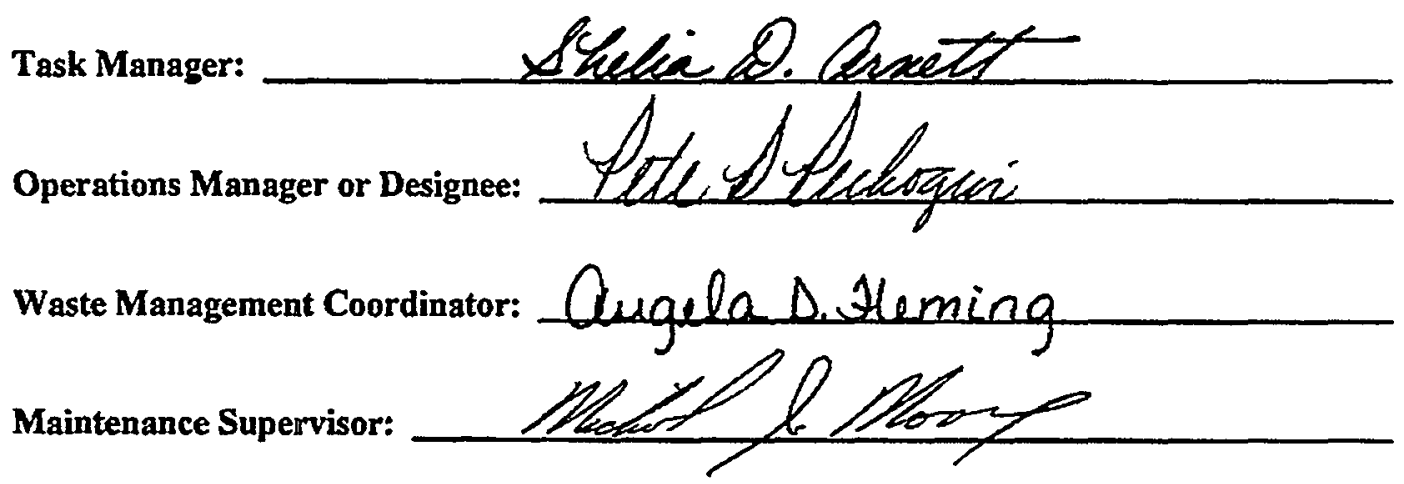

Health and Safety Representative: Laype 


\section{APPENDIX B. \\ EXHAUST DUCTWORK AND POTENTIAL RESIDUALS}


Plating bath and hood exhausts are tied into common ductwork throughout the building as shown in Figure 1. The exhaust fans have been deactivated but the ductwork has not been cleaned. The ductwork may contain residuals from the various operations. In meeting the LCAMs requirement, the ductwork and any residual that may remain are in a "stable condition." The following table provides a summary of the tanks, processes, and material types that have passed through the building exhaust systems. The information is based on process knowledge of the operations, chemical-make up of the plating baths, and legacy processing practices.

\begin{tabular}{|c|c|c|c|}
\hline $\begin{array}{c}\text { Exhaust } \\
\text { Fan } \\
\text { Number }\end{array}$ & $\begin{array}{l}\text { Plating Tank } \\
\text { Number }\end{array}$ & $\begin{array}{c}\text { Plating Operation or Bath } \\
\text { Designation }\end{array}$ & $\begin{array}{l}\text { Chemical Make-up and/or } \\
\text { Potential Bath Contaminants }\end{array}$ \\
\hline \multirow[t]{5}{*}{101} & 18 & Hydrochloric acid & Hydrochloric acid \\
\hline & 20 & Cold water rinse & \begin{tabular}{|l|} 
Water \\
\end{tabular} \\
\hline & 21 & Passivation & Nitric acid, sodium dichromate \\
\hline & 22 & $\begin{array}{l}\text { Hydrofluoric acid/nitric acid } \\
\text { pickle }\end{array}$ & Hydrofluoric acid, nitric acid \\
\hline & $25 \mathrm{~A}$ & Chromic acid strip & Chromic acid, phosphoric acid \\
\hline \multirow[t]{4}{*}{102} & $12(12 \mathrm{~A} \& 12 \mathrm{~B})$ & Caustic strip & Nickel, cyanide, caustic \\
\hline & 14 & Caustic strip & \begin{tabular}{|l}
$\begin{array}{l}\text { Caustic, } \\
\text { cadmium }\end{array}$ \\
cyanide, aluminum,
\end{tabular} \\
\hline & 16 & Black oxide coating & \begin{tabular}{|l|} 
Sodium hydroxide \\
\end{tabular} \\
\hline & 34 & Cyanide plating & Cyanide \\
\hline 103 & 3 & Metal cleaning & Hydrochloric acid \\
\hline \multirow[t]{3}{*}{104} & 1 & Caustic soak cleaner & Caustic \\
\hline & 2 & Caustic electroclean & Sodium hydroxide \\
\hline & 3 & Metal cleaning & Hydrochloric acid \\
\hline 105 & $\overline{\mathrm{NA}}$ & $\begin{array}{l}\text { Hood to degreasing operation } \\
\text { and caustic chromium strip }\end{array}$ & $\begin{array}{l}\text { Perchloroethylene, freon, caustic, } \\
\text { chromium, cyanide }\end{array}$ \\
\hline 106 & NA & Roto-clone & $\mathrm{NA}$ \\
\hline \multirow[t]{2}{*}{108} & $33 \mathrm{~A}$ & Vapor blaster glovebox & \begin{tabular}{|l} 
Aluminum oxide \\
\end{tabular} \\
\hline & $33 \mathrm{~B}$ & Vapor blaster glovebox & \begin{tabular}{|l} 
Aluminum oxide \\
\end{tabular} \\
\hline 109 & NA & Laboratory hoods & $\begin{array}{l}\text { Hydrochloric acid, hydrofluoric acid, } \\
\text { nitric acid, cyanide, nickel }\end{array}$ \\
\hline 110 & NA & Laboratory hoods & $\begin{array}{l}\text { Hydrochloric acid, hydrofluoric acid, } \\
\text { nitric acid, cyanide, nickel }\end{array}$ \\
\hline \multirow[t]{3}{*}{113} & 6 & Chrome plating & Chromic acid \\
\hline & 7 & Hot water rinse & Water \\
\hline & 8 & Nickel plating solution & Nickel sulfate, boric acid \\
\hline \multirow[t]{4}{*}{114} & Portable tank & Gold plating & Cyanide \\
\hline & 10 & Nickel plating & Nickel \\
\hline & 51 & Copper plating & Copper \\
\hline & 23 & Cadmium plating & \begin{tabular}{|l} 
Cadmium, sulfuric acid \\
\end{tabular} \\
\hline \multirow[t]{5}{*}{115} & 25 & Chromic acid anodize & Chromic acid \\
\hline & 26 & Hot water demineralized & Water \\
\hline & 37 & Electroless nickel & Nickel sulfate \\
\hline & 61 & Hydrochloric acid & Hydrochloric acid \\
\hline & 62 & Caustic cleaning & Sodium hydroxide \\
\hline
\end{tabular}




\begin{tabular}{|c|c|l|l|}
\hline $\begin{array}{c}\text { Exhaust } \\
\text { Fan } \\
\text { Number }\end{array}$ & $\begin{array}{c}\text { Plating Tank } \\
\text { Number }\end{array}$ & $\begin{array}{c}\text { Plating Operation or Bath } \\
\text { Designation }\end{array}$ & $\begin{array}{l}\text { Chemical Make-up and/or } \\
\text { Potential Bath Contaminants }\end{array}$ \\
\hline 116 & 1C & Water and black aluminum dye & Water, azo dye \\
\hline & $18 \mathrm{~B}$ & Chromate conversion & Chromic acid \\
\hline & 54 & Caustic cleaner and zincate & Caustic, zinc \\
\hline 117 & 56 & Nickel strike plating bath & Nickel chloride, hydrochloric acid \\
\hline & G & Nickel strip & Nickel, sulfuric acid \\
\hline & H & Black aluminum dye & Azo dye \\
\hline & J & Gold aluminum dye & Copper \\
\hline 118 & L & Black aluminum dye & Azo dye \\
\hline 119 & NA & Blue aluminum dye & Anthraquinone dye \\
\hline & 24 & Nitric acid & $\begin{array}{l}\text { Hydrochloric acid, hydrofluoric acid, } \\
\text { nitric acid, cyanide, nickel }\end{array}$ \\
\hline & 60 & Nickel and zinc plating & Nitric acid \\
\hline & D & Activator & Nickel chloride, zinc \\
\hline & E & Iridite & $\begin{array}{l}\text { Chromic acid,barium nitrate, } \\
\text { ferricyanide }\end{array}$ \\
\hline 120 & F & Alkaline strip & Caustic \\
\hline & 103 & Spare tank & Sulfuric acid \\
\hline & 104 & Electroless nickel & $\begin{array}{l}\text { Nitric acid, nickel, acetic acid, } \\
\text { sulfuric acid }\end{array}$ \\
\hline & 106 & Nickel strike & Nickel chloride, hydrochloric acid \\
\hline & 107 & Electroless nickel & $\begin{array}{l}\text { Nitric acid, nickel, acetic acid, } \\
\text { sulfuric acid }\end{array}$ \\
\hline & 109 & Nickel stripping & Nitric acid \\
\hline & NA & $\begin{array}{l}\text { Grinding room wash station } \\
\text { hood }\end{array}$ & $\begin{array}{l}\text { Methelyne chloride, freon, toluene, } \\
\text { perchloroethylene }\end{array}$ \\
\hline & & & \\
\hline
\end{tabular}

